\title{
The Mathematics Teachers Shift from the Traditional Teacher-Centred Classroom to a More Constructivist Student-Centred Epistemology
}

\author{
Iliya Joseph Bature \\ Batchelor Institute of Indigenous Tertiary Education, Charles Darwin University, Casuarina Campus, Darwin, Australia \\ Email: ijbature@yahoo.com
}

How to cite this paper: Bature, I.J. (2020) The Mathematics Teachers Shift from the Traditional Teacher-Centred Classroom to a More Constructivist Student-Centred Epistemology. Open Access Library Journal, 7: e6389.

https://doi.org/10.4236/oalib.1106389

Received: May 1, 2020

Accepted: May 24, 2020

Published: May 27, 2020

Copyright $\odot 2020$ by author(s) and Open Access Library Inc.

This work is licensed under the Creative Commons Attribution International License (CC BY 4.0).

http://creativecommons.org/licenses/by/4.0/

\begin{abstract}
This paper sought to look at the mathematics teachers' effort to shift from the traditional teacher-centered classroom instruction to a democratic student-centred classroom. Three research questions provided direction for the study. Four mathematics teachers participated in a qualitative case study research in a community of practice approach. They taught mathematics in two secondary schools for a period of 2 years. During this period, Six Senior secondary two students volunteered to participate in three focus group discussions on the effectiveness of the mathematics teacher's effort to shift from the traditional teacher-centred pedagogy to the student-centred approach. Classroom observations focus groups interviews and reflective interview were used as means of collecting data for the study. The findings of the study suggest that, the mathematics teachers had initial challenges shifting their traditional teacher-centred classrooms instruction to a more student-centred pedagogy. The findings also suggested that certain characteristics of the traditional teacher-centered classroom instructions were observed in the mathematics teachers' practice. The study shows the teachers resolved to shift their philosophy, and therefore developed strategies to foster its effectiveness. Some benefits of this strategy were outlined by the teachers and the focus group students. It was therefore recommended that, the need to shift classroom instruction in Nigeria from the traditional teacher-centered pedagogy to a student-centred pedagogy is non-negotiable. There is also an urgent need for mathematics teachers to relax the already tensed mathematics classroom climate, to foster positive teacher-students relationship as suggested in the constructivist philosophy.
\end{abstract}

\section{Subject Areas}

Mathematics Education 


\section{Keywords}

Student-Centered Learning, Teacher-Centered Learning, Mathematic

Teaching Pedagogies, Mathematics Teaching Strategies, Traditional

Classroom Instruction

\section{Introduction}

A teacher is a significant factor in any educational system [1]. No matter what amount of resources a nation puts into its education system, without proper preparation and motivation of teachers, there could be no positive impact in the development of education in that country [2] [3]. Therefore, the mandate to train and develop high level personnel in the teaching of mathematics cannot be over emphasized. The importance of teachers at all levels of education in Nigeria is also reflected in the National Policy on Education [4]. It declares that no educational system can rise above the quality of its teachers. This is supported by the view of Eso [5] who posited that competence, ability, resourcefulness, and ingenuity, ability to efficiently utilize the appropriate language, methodology and available instructional strategies are key basic attributes that should be found in a teacher. Abimbade [6] was of the view that teachers are said to be effective when their teaching leads to students' learning. Nothing has been taught until it has been learnt and this happens when the teacher succeeds in causing a change in understanding and behaviour of their learners.

Feldman [7] was also of the view that productive mathematics teachers are perceived to be knowledgeable in their subject matter, very organized and prepared for their classroom instruction and are enthusiastic in their approach to mathematics teaching in the classroom. Bajah [8] believed that productive mathematics teachers are those that can stimulate students' interest and have clarity of presentation of mathematical ideas. Bajah [8] went further to suggest that the important characteristics of productive mathematics teachers include course management and interpersonal traits such as helpfulness, openness, and friendliness.

The National Objectives of Mathematics in Nigeria highlight the necessity of mathematics teachers helping their students acquire necessary mathematical skill that will enable them function effectively [9]. This suggests that mathematics teachers have significant role on their students learning and therefore require the understanding of what students need to learn and the strategies to help challenge and support such students to learn them [10] [11] [12]. To achieve this, there is the need to develop mathematics teachers on the essential elements of pedagogical skills and strategies for effective classroom instruction [13] [14] [15]. The national objectives of Mathematics in Nigeria also emphasized this need of mathematics teachers developing an understanding of pedagogical content knowledge, skills and concepts necessary to build in our students' mathe- 
matical skills that will help them contribute meaningfully to their society [9] [13] [16].

The National Policy on Education spelt out the national education goals to include cultivating in students the act of inquiry, problem solving and having a rational mind for national development [9]. This suggests that these National goals for mathematics instruction are aimed at helping students acquire appropriate mental, physical and social skill, abilities and competencies that will equip them to live and contribute meaningfully to the development of their society. In view of these, research studies suggested that, mathematics teachers should teach mathematics through the hand-held approach to assist their student's problem-solving abilities, surround them with appropriate teaching resources that will help them take responsibility of their learning [17] [18] [19]. These suggest that achieving quality mathematics classroom instruction can only be possible when mathematics teachers adopt the constructivist epistemology in planning their content and in developing their pedagogical approaches to classroom instruction [13] [20] [21]. Since the mathematics curriculum in Nigerian is designed with the constructivist view to classroom instruction, there is the need for mathematics teachers in Nigeria to understand this epistemology and apply it to their mathematics instruction [17] [22].

The Nigerian Traditional Mathematics classroom: Teaching of mathematics in Nigeria is characterized by the traditional formula-based approach with emphasis on computation with little reference to mathematical reasoning and problem solving [14] [23]. According to the Bature and Bature [18] and NERDC [24] this type of teaching is mechanical and teacher-centred, and it is out-dated; since in this approach, mathematics is taught and learned instrumentally by rote and memorization, without meaningful understanding of concepts taught. Students become frustrated in the face of apparently meaningless symbols that are manipulated [14] [17] [24]. They regard mathematics as a static subject with a set of algorithms to be applied mechanically, as it is learnt through exercises or drill and practice [18] [24] [25] [26].

The mathematics classroom environment that is traditional is one in which the teacher is believed to be in possession or in control of the growth and development of understandings and monopolize communication during classroom instruction [17] [19] [27]. Students individually solve exercises in a teacher-dominated environment [17] [19] [28] [29]; which reflect the authoritarian, didactic approach to classroom instruction where the mathematics teacher monopolizes classroom activities [10] [28] [30]. This traditional approach permits the teacher to instruct the students traditionally [13] [30] [31]. This is a stark contrast to the national objectives of mathematics as indicated in the National Policy on Education that mathematics teachers should adopt the enquiry and the constructivist students-centred approaches to classroom instructions [24] [31]. Sad to infer here that these traditional patterns of mathematics teaching had remained largely unchanged and unchallenged [19] [28] [32]. 
Researchers globally had contributed to the discussions on the traditional, didactic teaching strategies particularly in the developing countries [33] [34] [35]. The findings of these researchers could be applied to the Nigerian mathematics classrooms. For example, Stodolsky, [36] asserted that most mathematics teachers concentrate their attentions on developing the computational teacher given curricula. This reflects the traditional mathematics classroom instruction in Nigeria where the development of computational skills by mathematics teachers occupies almost three-quarters of their time [10] [28] [30] [37]. Similarly, Schoenfield [38] identified mechanical procedures and symbolic manipulation as believed by most mathematics teachers to mean mathematical learning; even in "good" classrooms. Abimbade and Afolabi [39] and Bature and Atweh [14] complained that some mathematics teachers have consistently stuck to these traditional teacher-centred classroom instructions in Nigerian classrooms.

In their study, Igbokwe [25] and Ogunbiyi [26] and supported in the most recent study by Bature \& Atweh [10] [14] [30] asserted that the traditional teaching strategy commonly used in Nigeria is due to the lack of adequate instructional materials and teachers' unskilfulness in the use of effective teaching strategies. For these teachers, mathematics teaching simply implies memorizing, rule-bound algorithmic skills and procedures that are devoid of context or meaning [14] [24] [40]. This type of mathematics classroom teaching illustrates the trivialized, superficial learning that pervades the Nigerian mathematics classrooms [24] [28] [32] [33] [35].

The traditional teaching strategies still being adopted by mathematics teachers in Nigeria are based on the objectivist epistemology which has been questioned by many researchers globally and locally [33] [35] [41]. One of the major challenges in these traditional teaching strategies is that the teacher's perspective becomes the major determining factor in the resulting classroom environment [4] [15] [31]. For example, what teachers believe about classroom discourse influences the types of discussion that occur within the classrooms, so students have little or no influence in the direction of the discussion [10] [42]. According to Nelson [43], a widely used description of the traditional pattern in which the teacher's interpretations prevail is the initiation-reply-evaluation sequence. In this pattern, accordioning to Nelson [44]. And supported by Bature and Bundot [17] and Bature and Zuya [19] students respond to ideas and questions that are mostly teacher generated with little or no students-initiated learning. As a result, many students acquire procedural knowledge for step-by-step solutions to mathematical problems without students' understanding of the conceptual rationale behind the concept learnt [17] [18] [44]. Obviously, this pedagogical pattern is not equipping our students mathematically to live effectively in our contemporary age of science and technology [9] [24].

A shift to the Student-Centred Classroom Instruction: The replacement of classroom teaching that supports drill and memorization of mathematical procedures with classroom teaching that is student-centred and that supports stu- 
dents' engagement with conceptual issues of inquiry, collaboration and problem solving should be encouraged during classroom instruction. Consequently, this also implies that there is the need to shift from the traditional teacher-centred classroom instruction to a student-centred classroom instruction. Suggesting that this pattern of classroom instruction can be altered if mathematics teachers and their students are willing to shift their roles and beliefs [42]. Shifting the expectations of traditional mathematics classroom practice to a more engaged system where everyone is involved makes mathematics classroom instruction real and engaging to all students [10] [14] [30].

Empirical studies by Wilson and Lloyd [42] supported by Bature and Atweh [10] suggests that mathematics teachers who want to shift from the traditional mathematics classroom to student-centred epistemology should learn to adopt strategies that will encourage interactions, collaboration, students' participation and engagement. This suggest that the concept of shift from the teachers' control mathematic classroom instruction to a more relaxed classroom environment where learning will be done collaboratively in a more non-authoritative way does not necessarily imply that the mathematics teachers' authority is completely discounted [10] [31] [34] [42]. Rather, it makes mathematics teachers emphasize student involvement by decreasing their traditional role of givers of knowledge and playing a more relaxed role of guiding students' knowledge and learning [14] [42].

Theories of teaching and learning based on constructivist principles suggest that students as active learners view mathematical learning as active manipulation of meanings [45]. This means that mathematics teachers desiring to achieve constructivist principles in their classroom instruction should be able to provide learning environments that will help challenge their students' critical thinking. This constructivist epistemology that guides students' thinking suggests a shift from the traditional teaching strategies which seek to transmit fixed, well-structured knowledge with a firm external control of content, sequence and pace of learning by the mathematics teacher to a more relaxed, collaborative and participative student-centred learning where students construct their own knowledge, learn more independently and in the process acquire self-reliance [45] [46].

Piaget's contributions are essentially built on the basic idea that knowledge derives from the adaptation of the individual to the environment, is much richer than knowledge received by mere recitations or procedural presentation of facts by the traditional mathematics teacher [43]. This principle suggests that rich knowledge can be traced to students' ability to interact with the objects around them. This also suggests that to encourage such interactions among students during classroom instruction mathematics teachers should be able to provide activities through which students can use their experiences to gain purposeful knowledge that can later be applied in other situations that may arise in the future [46]. Suggesting that, mathematics classroom instruction where students' ideas are solicited and valued as important contributions to developing understanding of concepts and problems should be valued [14] [42]. In these class- 
rooms, teachers become collaborating members as the learning environment evolves [17] [19] [47].

The work of Bruner [48], provides another perspective from which to view current mathematics classroom reforms, as we attempt to provide students with meaningful learning environments. Brunner [48] was of the view that "Culturally adapted way of life depends upon shared meanings and shared modes of discourse for negotiating differences in meaning and interpretation" (p. 13). This view of Bruner, [48] centred on the concept of shared ideas, negotiation of meanings, defence and counter defence of mathematics understanding among students during mathematics instruction which form the hub of this study.

This paper seeks to look at the need to shift from the traditional mathematics classroom instruction that dwelled on the teacher centre epistemology to a modern student-centred epistemology where all our students will be the centred of the instruction instead of the teacher. Specifically, the following research objectives will be used to guide the investigation.

- To investigate the evidence of the traditional teacher-centered approach observed in the mathematics teachers' classroom instruction.

- To investigate the strategies adopted by the mathematics teachers to shift from the traditional teacher-centred learning to student-centred learning.

- To investigate the perception of the mathematics teachers and students on the student-centred learning epistemology.

Design: This research adopted the Qualitative approach to investigating the classroom teaching of four mathematics teachers. They were teaching mathematics in two secondary schools working in the community of practice to improve their teaching. This epistemology was first introduced by cognitive anthropologist Jean Lave and an educational theorist Etienne Wenger in 1991 [49]. The concept of community of practice evolve naturally because of the members of the community having the same interest in researching a domain or area of interest with the purpose of gaining new knowledge in that area. This knowledge gained through a process of sharing ideas and thoughts among the members of the group [49]. Community of practice can be viewed as a process of two or more researchers or teachers engaging in a process of conceptual or empirical enquiry into a common case of concern [50]. In this case; adopting the student-centred approach to classroom instruction as against the traditional mathematics classroom teaching approach that had pervaded the Nigerian mathematics classroom was the issue of concern to these four mathematics teachers.

Participants: Four mathematics teachers John, James, Jacob and Joy (Pseudonyms), with a considerable years of teaching experience (5 to 7 years) volunteered to work with the researcher in a community of practice for a period of about two years to explore this epistemology in two secondary schools in Northern Nigeria. The four mathematics teachers taught three classes in two secondary schools within the period using a community of practice approach. There was a follow up investigation of two of the four teachers a year later to observe their progress in the used of the new pedagogy. Six students from senior sec- 
ondary two voluntarily agreed to participate in series of focus group interviews with the researcher on the classroom instruction of the four mathematics teachers. The six students were Mary, Martha, and Martina (girls) and Victor, Moses, and Simon (Boys) (Pseudonym).

Instrument and instrumentation: Classroom instructions, reflective interviews and the focus group interviews with the six students and their classmates were videotaped. While a Research Journal was kept by the researcher to record observations that were probably not captured by the video recordings. The following instruments were used to obtained data for the study.

Observation: The researcher adopted the observational strategy to obtained data for the study. There were both in-class observation of teachers and students practice and the out-class observation through reflective interviews and focus groups interviews. The in-class observation was done to measure behaviours of both teachers and students during classroom instruction. The out-class observations were used to measure the mathematics teacher reflection meeting, questions and answer sessions with both teachers and students or during the focus groups interviews with the 6 students. All actions related to the research objectives were captured both in writing and in video recording.

Reflective Interview: There was a two-hour reflective interview after every three weeks of teaching. The researcher and the Mathematics teachers met and reviewed the teaching and discussed their weaknesses and strength, develop and discuss strategies to improve their weaknesses before launching into the next three weeks.

Focus Group Interview. The six students selected were invited for focus group interviews after every three weeks of teaching. The researcher meets with the Focus group students and discusses their perception of the new classrooms created by the mathematics teachers and the benefits they gain participating in the classroom teaching of the selected teachers.

Research Journal: The researcher kept a Research Journals to record all other observations and interactions with either the teachers or the students. Particularly those actions and reactions or behaviours that were not captured by the video.

Validation of the Instruments. Several techniques were adopted by the researchers to validate the instruments used in collecting data for this research. The first step of ensuring the validity of the data collected was choosing a well-trained and skilled moderator or facilitator to look at the quality of the data collected. This was done by a senior academic in the faculty of education. The moderator checked personal biases and expectations of the research. While a good moderator is key, another strategy adopted to validate the data is the choice of the sample group. The participants were truly members of the segment from which they are recruited. The research also employed ethical recruiting to collect data from mathematics education specialists who are truly representative of their segment, which the researchers believe will lead to achieving a valid result. The researcher also employed triangulation strategy to validate the data by 
adopting multiple perspectives of using several moderators, and different locations with the view of getting the results from different angles. There were also the respondent validation strategies, deep saturation into the research with the view of promoting validity and finally, there was the seeking of an alternative explanation of ideas from the participants.

Ethical Issues: Appropriate ethical issues that involve taking permission from the school and the parents of the students used for this study were followed. For example, all the students used in the study voluntarily consented to participate in the focus group interviews and some intermittent interviews. Before then, the researcher has obtained relevant ethical permission from the school to carry out the research. Since the research was conducted with minors, the principals sent consent forms to the parents of the affected students, and they gave their permission in writing to the principal of the schools before the research commences. Relevant consents were also obtained from the mathematics teachers used for the study.

Data Analysis: Data analyses in this paper concentrated on the reflective interviews on views and the observations of the mathematics teachers and the researcher on their reflection on the use of Productive Pedagogies as a tool to reform their classroom practice. The narrative approach was adopted to analyse the data collected through reflective practice of the mathematics teachers. This agrees with the views of Clandinin and Connelly [51] who were of the view that narrative could be used in analysing research data that the researcher might have recorded, or a story through a journal, diary or that the researcher might have observed individuals and records fieldnotes during data collection. During narratives the researcher seeks to identify themes, categories, and patterns in order to determine relationship between the themes identified and the response of the subjects to the research questions. After which the research will begin to make to data collected through a process of rigorous and constant comparisons of related themes [52] [53].

While conducting qualitative research, researchers collect large chucked of data, either through observations or as in this case, through reflective interviews. After the data were collected, the research sat down and watched the videos, transcribed all that was recorded into a written document. After this process the researchers read through the transcripts and begin to group the ideas into themes, codes and patterns, with the view of making meaning of the data. Research studies suggest that, there are two approaches to thematic analysis [54]. The researcher could decide to use inductive thematic analysis which allows the data to determine the themes to be used or a deductive analysis where the researcher comes to the data with some preconceived themes [54] [55] [56]. In this paper, the researcher adopted both the inductive and the deductive themes to approach the data analysis. In data analysis themes majorly, key words used to group the data into reasonable patterns or codes. Therefore, the data collected were codded and all the codes were sorted into different themes by grouping the mathematics teachers' comments, views and perceptions into related patterns. 
After which, the researcher began to make meanings of themes through the process called analysis.

\section{Results}

\section{Demonstrating the Traditional Teacher-Centred Approach to Classroom} Instruction:

Research Objective 1: To investigate the evidence of the traditional teacher-centered approach observed in the mathematics teachers classroom instruction.

During the preparatory meetings for this research, the researcher and the mathematics teachers discussed extensively on the importance of student-centred learning and how it can help improve students' engagement and teacher-students relationship during classroom instruction. Some of the mathematics teachers were of the view that such student-centred learning is not possible in the Nigerian classroom setting. They argued that adopting student-centered learning could lead to students taking over their classrooms and make instructions difficult or make classroom environment distractive and ungovernable to them and other students. Data collected in this study suggest that the mathematics teachers in their initial classroom practice demonstrated some characteristics of traditional classroom instruction. Some of which are discussed below;

Mathematics Teachers' Strict and Domineering Classroom Instruction: The first observable evidence of traditional teacher-centered classroom during the research is the teacher domineering attitude to classroom activities. For example, John argued that mathematics teachers are to explicitly determine what activities students should do and how such activities should be done rather than leaving students working on their own.

When the teacher is in the class, he is supposed to be in control of all the activities in his class. He should be in-charge of directing all the affairs of his class, allowing students to take control of the classroom activities might be counterproductive. (John: Researchers Journal)

In view of this perception of John, the focus group students were of the view that this domineering attitude of teachers make student dislike mathematics, suggesting that students' problems in mathematics are not restricted to their negative attitude but could be traced to mathematics teachers' domineering attitude.

Sometimes sir ..., the mood in your face alone makes people to be attracted or run away from you ..., if your mood is friendly the students will be willing to listen to you. But when your mood is not friendly and you tight your face, I personally will fear you and whatever you are saying, I will not pay attention to you, and I will not enjoy or understand what you are saying as a teacher in the class. (Martha: Focus Group Interview).

Strict and Authoritarian Classroom Control During Instruction: Data collected suggested that the there was evidence of strict and authoritarian class- 
room control during their initial classroom instruction. Strict classroom control is widely held among Nigerian mathematics teachers as one of the strategies to manage student's misbehaviour during classroom instruction. John argued.

There are students who will never learn anything in the class if the teacher did not subject such students to some sort of punishment ..., this student-centred philosophy might not be possible for such students ..., they must be disciplined (punished), if the teacher will get them solved problems ... (John: Researcher's Journal).

Another teacher supported John by saying

If we hope to have a classroom where student needs are identified and met, discipline (punishment) must be enforced even if the teacher is going to "use the cane". This is because, there are students in our classes that will never learn if they are not "pushed" (Jacob: Researcher's Journal).

Yes, there are students in our classes today ..., if the teacher did not apply some pains to them, there will be no gain ..., Shebi ..., the idea is to carry everybody along ..., whether slow learners or the gifted ones ..., carrying them along and making sure they participate in classroom activities, requires some pains. (Jacob; Researcher's Journal)

This was demonstrated in the classroom practice of the teachers in the earliest part of the research. However, evidence in literature suggest such disciplinary approach to classroom management had not helped students' engagement in mathematics. It has rather brought a wider gap between teachers and students. From the views of the students, they are finding it hard to learn mathematics today, because of the mathematics teachers' strict stand on how mathematics should be learnt or taught.

Generally, in most mathematics classrooms, teachers are too strict, this sometimes-scared student away from participating in classroom activities ... (Mary, Focus Group), Yes Mary ... in my own understanding mathematics teachers are not supposed to be strict because students are finding it hard today to learn mathematics. (Martha: Focus Group Interview)

Mary and Martha's view suggests that, mathematics teachers' strict stands during classroom instructions makes it difficult for students to learn mathematics and sometimes causes students mathematics phobia and disengagement. Suggesting that, when mathematics teachers are friendly and approachable, students' attitude and engagement in mathematics increases.

Mathematics Teachers Unfriendly Classroom Climate: Data collected in this study suggest that one of the key evidences of the traditional teacher-centered approach to classroom instruction is the unfriendly attitude of mathematics teachers to students during classroom instruction. For example, in the case where mathematics teachers did not provide classrooms where students engagement is not encouraged

I must confess ..., Yes ..., In my effort to instill discipline in my class, I did not give my students room for discussion or interaction ..., they were denied ..., I did that on purpose ... I insisted they should be quiet in the class and listen 
when I am teaching ..., I did not want distraction ..., This has always been my practice... (Joy: Reflective Interview)

From the view of Joy, it is important for their students to sit quietly in the class and listen to the teachers dish out instructions to their students. However, students frown at this classroom climate because it makes them mere listeners instead of creators of their own learning.

The mathematics teachers were too strict, too over-serious, and they were not friendly, I mean they did not allow the students a breathing space; they sometimes shout the student down at the slightest mistake by the student. (Mary. Focus Group interview). Some of the teachers where too serious and unfriendly for my liking (Martha: Focus Group interview). Some were too fast and have no students interest in mind; (Moses: Focus Group interview)

This suggest that, the classroom climate created by mathematics teachers means a lot to students. If teachers are friendly and accommodating, the students will cooperate with the teachers during classroom instruction. But if otherwise, no matter how good such a teacher is, students pay less attention to the teacher's classroom teaching. Martha argued,

See sir, sometimes the mood in your face alone makes people to be attracted or run away from you. If your mood is friendly the students will be willing to listen to you. But when your mood is not friendly, and you tie your face, I personally will fear you and whatever you are saying, I will not pay attention to you. I will not enjoy or understand what you are saying as a teacher ..., (Martha: Focus Group Interview)

This view suggests that effective classroom instruction is that classroom where teachers create a democratic classroom climate where students interact with their peers and the teacher to identify their strength and weakness in a community of friendship. In such classrooms, ideas are shared, successes are also shared among members of the community, difficulties and confusions are discuss, research and possible solutions are sought for in a free and fair environment.

Mathematics Teachers Monopoly of Knowledge: Data collected in this research suggest that there was observable evidence of traditional teacher-centered classroom instruction where mathematics teachers monopolize communication in the classroom. For example, the teachers were seen working alone without providing opportunities for their students' self-generation of knowledge.

One of the teachers teaching us was just working alone, he was just writing on the board. Even when he gives students problems to solve, he will not allow us to try the problem, he will just go to the board and solve the problem, and students were not part of the lesson. When he finished, he will simply ask us to copy (Moses: Focus Group Interview).

From the view of the students, the mathematics teachers were simply talking to themselves, the students' views were not valued as important.

Yes ..., sir, I observed most of the teachers ..., particularly one of them, he was just talking alone ..., and was too serious ..., this created fear in me and 
some of the students in my group. To me it seems the teacher never believe in us ..., He was just talking to the board ..., the teacher did not have students in mind (Martina: Focus Group interview).

In his effort to justify this, John was of the view that sometimes-allowing students take responsibility of their learning or have control of the learning activities in the class might lead to wasting classroom teaching time and hence will make it difficult for the teacher to achieve his/her objective.

The truth is that for effective teaching in my view, the mathematics teacher must dominate and control the classroom activities. If not sir ..., one will find it difficult finishing what he has prepared for the class. (John: Reflective interview)

Perhaps this view demonstrated the ignorance's of these mathematics teachers on the effectiveness of the student-centred learning strategy, because, students will not only learn more through these pedagogies but, they will assimilate the learning materials faster.

Students' Passive Involvement in Classroom Instruction: Data collected from the study suggested that one of the evidences of the traditional teacher-centred classrooms observed was the Students' passive involvement in classroom instructions. In this type of classrooms, the teacher does the teaching and all the talking, while the students do the listening and only respond when they are asked.

I must confess ..., Yes ..., In my effort to instil discipline in my class, I did not give my students room for discussion or interaction ..., they were denied ..., I did that on purpose ... I insisted they should be quiet in the class and listen when I am teaching ..., I did not want distraction ..., This has always been my practice... (Joy: Reflective interview)

This does not make mathematics classroom instruction interesting and hence make students dislike mathematics and indeed the mathematics teachers. According to the focus group students, some teachers can go as far as sending students out of the class if they discover such students are trying to share ideas with one another during classroom teaching. Mary said,

You sometimes find it difficult to understand what the mathematics teacher is saying, and you dare not talk. Or asked your classmates ..., the teachers give us no opportunity to contribute to the classroom instruction ..., they preferred we sit and listened (Mary, Focus Group Interview).

That is true Mary, sometimes the teachers will even send you out of their class if you asked questions or trying to contribute to classroom instruction ... All they want from us is to copy examples when they finished ... (Martha: Focus Group interview)

Strategies to Create a Shift to a Student-Centered Learning Classroom

Research Objective 2: To investigate the strategies adopted by mathematics teachers to shift from the traditional teacher-centred learning to student-centred learning.

In view of the challenges faced by the mathematics teachers above, it became imperative that the traditional teacher-centred approach had not provide 
enough solution to the problems facing mathematics teachers and their students during classroom instruction. This is because there are lots of information in literature that suggests students sometimes demonstrate some un-wanted and un-appreciated behaviours in the class when teachers' traditional system of instruction is being implemented. For example, students tend to create unnecessary apprehension during classroom teaching to demonstrate their feelings. Therefore, the mathematics teachers resolved to change their approach to teaching from the traditional teacher-centred approach to a student-centred approach.

Developing Responsive Classroom Environment. Data collected suggest that, when teachers create a responsive classroom environment for their students, students tend to relax and be less apprehensive during classroom instruction. But if otherwise, students tend to resist such attitude in their own way. Martha asserted that;

See sir, sometimes the mood in the teacher's face can makes students to be attracted or run away from the teacher. If the teacher's mood is friendly the students will be willing to listen him/her. But when the mood is not friendly, and the teacher tie his/ her face, I personally will be scared of the teacher and whatever hel she is saying, I will not pay attention to it. I will not enjoy or understand the lesson. (Martha: Focus Group Interview)

From the perspectives of the students, some of their teachers were too serious and lacked good classroom relationship. Hence, make the students find it difficult to participate in classroom activities. Therefore, the students suggested that a free and fair classroom climate will provide students opportunity to contribute meaningfully to classroom instruction.

Students really need a free and fair classroom environment where everybody will have the opportunity to approach the teacher on areas of misunderstanding ..., in an atmosphere of love and friendship. (Mary. Focus Group Interview)

This type of classroom instruction transforms the unfriendly climate, conflicts of relationship to a classroom full of love and friendship. From the view of the students the mathematics teachers gradually build this among their students. Positive teacher-student relationships were built during the classroom instruction. John affirmed,

Yes, we started slowly ..., it was not easy initially ..., but from my observation of the classes taught by my colleagues I observed they gradually demonstrated positive feelings and attitude towards their students ..., I don't know what others observed about me ..., but I also tried. (John: Reflective interview)

Supporting this view, Martha sees the benefits of such relationship and asserted that it helps students take responsibility of their learning and increases students' positive attitude to learning.

Sir, in my view students who have close, positive and supportive relationships with their teachers usually pay closer attention to the teachers than those students with more conflicting relationships ..., and from my observation in the 
classroom teaching of our teachers ..., they gradually built such trust or relationship with us ..., (Martha: Focus group Interviews).

Similarly, from the views of Martha, it is pertinent to observe that mathematics teachers' personality during classroom teaching could promote effective student-centred engagement during classroom instruction. Data collected suggested that developing positive personality before students draw students closer to the teacher thereby helped promote the desire in students to learn.

Sir, if mathematics teacher present himself friendly and approachable to students, create positive relationships with students ..., create classroom environments that gives students voices to be counted during classroom instruction (Student-centered ...), it will foster (help) the social, and academic progress of the students ..., students will be happy working with their teachers and their colleagues (Martha: Focus Group Interview).

This assertion suggests that, if students have personal connection with their teachers, experience frequent communication, and receive more guidance and praise than criticism, such students become more trustful, independent and willing to take risks and responsibility.

Developing Student Self-Discipline (Self-Regulation): Data collected in this study suggest that to foster effective student-centred approach, the mathematics teachers introduced students' self-regulation. This view was suggested by Joy who asserted that instead of carrying cane around as a teacher there is need for teachers to encourage students' self-regulation.

Sir ..., truly ..., from the African cultural perspectives; there is nothing wrong with the use of cane, but ..., in my own view this should not control the class ..., as mathematics teachers, I feel we should inculcate in students' self-discipline rather than carrying cane about like cow-boys (Joy: Researchers Journal).

From the view of Joy, it is suggested that, teaching students or guiding students to be self-disciplined is better that enforcing discipline in the class. She was of the view that, it is a better strategy to teach students to be self-discipline than carrying a cane.

In my view we are better of teaching our students to be self-discipline instead of using cane ..., It all depends on the way teachers approach it. I think I have learnt that this self-regulation is good for our students instead of carrying cane about. (Joy: Researchers Journal)

The mathematics teachers adopted this strategy and it was observed it helped model modelled their student's behaviour than when they were carrying cane around to scare students away from them.

When the teachers came back after our focus group interview, I observed a gradual change, it's like the strengthen their teaching (pedagogy), it starts like going to be distractive, but we were so busy (engaged) in our task that we had no time distracting the class ... (Micah: Focus group Interview)

... yes Micah (cut in) to my amazement as we progress, those students that will generally cause trouble and make the classroom distractive were so (busy) 
engaged that they had no opportunity causing their usual troubles ... I like it sha ... (Mary, Focus group Interview).

Developing Problems Solving Strategy to Solve Difficult Mathematics Problems: Data collected in the study suggest that problem solving strategies among students can encourage students-centred learning. From the assertion of Micah and Mary, the mathematics teachers strengthen their pedagogy and got them engage in problem solving, hence gave them no opportunity to distract the class. From the view of James below problem solving is one of the keys that could encourage student-centred learning in mathematics classrooms.

I came up with an idea of providing my students with a complex problem ... provided them with initial information ... and asked them to provide me with the solution of the problem ..., this got my students engaged ..., From my observation this got my students busy ..., they Students reconstructed the problem ..., they argued ..., asked Questions ..., in the quest to find solution to the challenging question ..., I allowed my students to battle the question and come up with their solution, I saw the evidence of student-centeredness in their conversation ..., my students were seen working together ..., asking questions from one another, seeking direction to the problem ..., I observed student-centred conversation as against the teacher self-centred approach observed in our earlier classroom instructions. (James: Reflective Interview)

Joy also commented on her effort using problem solving and said,

In my view after the criticisms from the students ..., I came really prepared, my colleagues also ..., We can really see students' centeredness through effective classroom engagement going on. Student interaction was going on with little teachers' involvement, the students were battling the problems alone ..., This shows improvement from my initial teacher-centred approach. (Joy: Reflective Interview)

..., we got our students working on their own, we were only moving around to see what they are doing and offer helps where necessary. We created challenging and high intellectual problems for them ..., I observed in Johns class some of the students using their background knowledge of surd, to solve quadratic equations ..., (Joy: Reflective Interview).

Yes sir ..., Joy is right ..., for example, I observed in my class, from the question given to the student which was critical and challenging ..., they had to use their knowledge of surd and also indices in order to really bring out the solution of the quadratic equation. Without this, the students would have found it difficult to crack the difficult and the highly Intellectual question given to them. Hahn ... I was proud of those students ..., Myself too! (John: Reflective Interview)

This suggests that when teachers get their students involved in problems solving, it fosters student-centred engagement, gives the students the freedom for initiation and construction of knowledge, students tend to use their initiatives to identify possible strategies to solve their problems. 
Perception of Teachers and Student on the Benefits of Shifting Towards Student-Centered Pedagogy:

Research Objective 3: To investigate the perception of Mathematics teachers and students on the student-centred learning epistemology.

The change in the mathematics teachers approach to classroom instruction brought about a change in classroom environment, atmosphere and relationships generally. This suggests that when mathematics teachers adopt student-centred approach to classroom instructions, the general teacher domineering attitude reduce, and a more relax democratic classrooms where students are at the centre of learning and teacher providing background support and supervision is enforced.

Sir, in my own view ..., this time ... I think, the teachers were relaxed, students engagement and collaboration increased ... (Mary Focus Group Interview) ...

Yes Mary, good to hear this from you ..., what did you observed? (Researcher. Focus group Discussion)

Sir, ..., (we) students truly need a free and fair classroom environment to strive. we need an environment where everybody will have the opportunity to approach his/ her colleagues or the teacher on areas of misunderstanding or difficulties ..., I said this before ..., and I observed this demonstrated by our teachers ..., its good ..., I like it ... (Mary. Focus Group interview)

Sir, I think this is good and Mary is right, when mathematics teachers recognise and respect the views of their students, stopped being harsh, domineering and unfriendly, and created cordial teacher-student relationship, we enjoyed such teaching ... its good (Martina; Focus group Interview).

From the views of the students above such climates provide opportunities for students to contribute profitably to classroom instruction and they become relaxed as against the tense mathematics classroom observed in most Nigerian mathematics classrooms. Martha said;

The new student-centred instruction brought about good and cordial student-teacher relationship, This helped effective relationship among students also, I could see how this helps student's confidence in Mathematics ... I wonder how this change was so natural and dramatic. (Martha: Focus Group interview)

It's like someone is always there ... very close to you ... to say, $O$ gir? Is there any problem? Do it this way, this way, and this way. The classmates also ... the teachers ... are always there ... willing to assist ... willing to show the way. (Martina: Focus Group interview)

The classroom environment created by the teachers brought about unity and love among us (students). This also brought about excellent cooperation between students and between teachers and students. (Mary. Focus Group Interview)

Similar observations were made by the Mathematics teachers. For example, Joy observed ..., 
This time around sir, the teachers created classrooms were students-centred engagement was encouraged ..., For example, the students were fully involved in my classroom instruction compared to my strict teacher-centred approach adopted earlier ..., it was also observed that my students were relaxed to discuss their problems with their colleagues and with the teacher. (Joy: Reflective interview)

From the data collected it was observed that the introduction of the student-centered pedagogies makes mathematics classroom democratic as against the autocratic traditional teacher-centered pedagogies.

In my view we really tried ..., the students cooperated also ..., the teachers were so lenient ..., particularly John ... honestly sir ..., (looked at John and then laugh) ..., there was truly a shift from his traditional bossy classroom instruction to a more democratic system ..., Kai ...? Before ..., sometimes ..., towards the end ..., if he brings that face ..., it really, really, gets students scared ..., ( $I$ was watching you John ...,) smile ..., (Joy: Reflective Interview)

This only suggests that, when mathematics teachers relax their classroom environment and become student-friendly, student-centred classroom instruction becomes visible, this helps students take responsibility of their learning, create their own pedagogies and knowledge, thereby increases their confidence, and participation even among students with learning difficulties. John said,

My classroom used to be like a graveyard ..., students dare not talk when I am teaching ..., but to my amazement my class naturally became interactive, the students interacted in their groups, finding solution to their problem and even those who fear mathematics you can see them ready to defend their solutions. (John: Reflective Interview)

Similarly, the students also observed the change of teaching approach in Johns' classroom teaching. For example, the students asserted;

John gave no room for students' views in his earlier classrooms instruction, when he started ..., he was very strict ..., we were very scared of him; but as he progress, he became more democratic ..., very intelligent in organizing students and in doing what he wanted us to be doing ..., (Martina: Focus Group Interview).

That is true Martina, the John of all people asked of students opinions in solving problems in the class ..., he was not interfering with our problem-solving activities ..., this gave us some freedom to relax and discuss our concerned with him ... (Martha: Focus Group Interview)

Sincerely, At the beginning I was afraid of him ..., but after our first meeting ..., it was a different John we saw, we took control of our learning ..., we were in charge of our learning ..., despite his difficult Questions, Students cooperated ..., we collaborated ..., and he was so good ..., supportive ..., kind ..., wonderful ..., I like him ... (everybody laughed ...) (Mary. Focus Group Interview)

Cut in ... Ahh ... Mary!! ... Like Him!!? ..., Hmmm ..., (laughing continues) ..., he was a good teacher Sha ... (Victor. Focus Group) 
These suggests that when teachers relax their classroom atmosphere students work independently, become accountable and motivated to work harder, and take risks on their learning, suggesting another benefit of student-centeredness during classroom instruction;

In my observations of the classroom instruction of the mathematics teachers, their students were profitably engaged in creating and constructing their knowledge, through active participation with the learning materials provided by the mathematics teachers. The students became contributors of knowledge instead of being passive recipients of knowledge as observed in the traditional mathematics classrooms. This was possible because, the teachers adopted some strategies to foster their instruction, their hard stand on students on sit and listen pedagogy reduced, and they provided the students with opportunities of being responsible for their learning (Researchers Journal).

\section{Findings and Discussions}

This section is discussed using three themes. First the researcher will look at the traditional teacher centred classrooms that had prevailed in the Nigerian mathematics classrooms. Secondly the researcher will look at the strategies adopted by the mathematics teachers to foster students centred classroom practice. And the third theme will be the benefits of the students centred epistemology in Mathematics classrooms instruction.

Traditional Teacher-Centred Mathematics Classroom Instructions in Nigeria. The perception of the Mathematics teachers from the study suggests that they did not adopt the principles of student-centred approach without critically considering their cultural and environmental factors and the Nigerian mathematics classroom context. Therefore, the teachers argued that allowing student-centred pedagogy in the Nigerian classroom context could be counterproductive. The research report in literature, support this view by asserting mathematics teachers in most developing countries are finding it difficult to move away from rote learning towards the constructivist epistemology [24] [39]. Perhaps, one could deduce that these mathematics teachers are so entrenched in their old habits of teacher-centred traditional classroom teaching [28] [30] [32], that they failed to imagine alternatives that could be adopted to achieve quality classroom teaching [5] [6]. Similarly, these mathematics teachers failed to accept the fact that in developing positive and mutually supportive mathematics classroom relationships, breaking down power imbalances between the teacher and his students is necessary [57] [58].

The findings of the study suggest that the mathematics teachers demonstrated different characteristics of traditional teacher-centered pedagogy during their initial teaching practice. First, there was the evidence of the teacher-domineering approach to classroom instruction. Brophy [27], argued that, this type of classrooms instruction is traditional, the teacher is believed to be in possession or in control of the growth and development of understandings, dominate classroom 
discussion, and maintain basic structure in that heavily relies on the teacher's knowledge [10] [14] [30] [37]. Students' voices in this type of classrooms are not recognised [10] [31]. Second, there was the presence of strict and authoritarian mathematics classroom teaching approach demonstrated by the mathematics teachers. One major concern of this epistemology is the fact that the teacher's perspective becomes the major determining factor in the resulting classroom environment [4] [17].

The third characteristic suggests the fact that the mathematics teachers demonstrated an unfriendly classroom climate and relationship with their students. Research studies suggest that unfriendly classroom climates create apprehension among students and makes classroom engagement and interaction difficult [18] [41]. Students in this type of classroom remain timid and fearful, student's confidence was not explored, their abilities are not tested because they rely heavily on the monopolistic expertise of the mathematics teacher. The fourth characteristic observed in the mathematics teachers' classroom instruction was the demonstration of the monopoly of knowledge by the mathematics teachers. This philosophy tallies with the findings of Good and Brophy [37]. They asserted that in this type of mathematics classrooms, the teacher is believing to be in possession and control of the growth and development of understandings, monopolizes communication during classroom instruction [27], dominates classroom discussion, and maintained structures that heavily rely on the teacher [14] [30] [37].

This philosophy is closely related to the last characteristics of the traditional teacher-centered classroom instruction. The findings of the study suggested that in most traditional teacher-centered classrooms where teachers hold the monopoly of knowledge there is always the evidence of student's passive involvement in classroom activities. In such classrooms, teachers instruct their students traditionally, controls classroom talk, and monopolize communication [13]. In this approach, mathematics is taught and learned instrumentally by rote and memorization, without meaningful understanding of concepts taught [10] [15] [24] [31].

Mathematics Teachers Shift Towards Student-Centred Instructional Approach: The principle of shift to the student-centred approach to classroom instruction in Nigerian is not new to classroom teachers. Series of workshops and professional development programs have been organised to update teachers' pedagogical knowledge in using modern instructional approaches have been designed and implemented [44] [59] [60]. However, most mathematics teachers and indeed teachers generally, seem not to have attempted demonstrating it in their classroom instruction [61]. Sad to infer here that these patterns of mathematics classroom instruction had remained largely unchanged and unchallenged [28] [32]. Other teachers believe that, since they were not taught using the most engaging pedagogies, there is no need stressing themselves to develop strategies they are not quite familiar with [10] [13] [31]. 
In view of the challenges faced by the mathematics teachers, it became imperative that shifting from the traditional teacher-centered approach to the student centre epistemology was a bit of a challenge to them. However, they were resolved to make this shift possible and realistic. Wilson and Lloyd [42] suggested that, the first thing teachers and students will do if this shift will be a possibility, is to first show the willingness to shift their roles and believes. The resolve of mathematics teachers and their students is supported by the constructivist epistemology that guides our thinking that, the shift from the traditional teacher-centered strategies which seek to transmit fixed, well-structured knowledge with a firm external control of content, sequence and pace of learning to a more relaxed, collaborative and participative student-centred learning where students construct their own knowledge, learn more independently and in the process acquire self-reliance should be made a priority [46] [62].

Like the resolve of the mathematics teachers to shift roles and believes, they also resolved to work together with the students and decided to shelve some of their domineering and monopolistic authoritarian tendencies to provide relaxed classroom climate where knowledge is shared, negotiated, dialogued and debated [31]. This is related to the contemporary interpretation of the Vygotsky' epistemology by Lave and Wenger Lave and Wenger [49]. They argue that learning is most effective when it is co-constructed in the context in which it is applied. This epistemology suggests that student-centered learning support collaborative learning activities that are carried out in an authentic environment using pedagogical strategies that model students' real-life related issues [63]. This gave the students some opportunities to take control of their classroom activities, approach their learning in a more socialist perspective as against the passive students' participation in classroom instruction that prevailed during the authoritarian traditional teacher-centered epistemology [10] [17] [46] [47].

Intensive literature reviews and discussions during reflective meetings between the researcher and the teachers were intensified. It is true in literature that, there are many teachers' professional development programs in developing countries. These programs are aimed at helping mathematics teachers shift from the traditional teacher-centered learning of rote learning and transmission models of information to a constructivist model of student-centered epistemology. However, such effort had always being a challenge when it comes to implementation in classrooms [10] [30] [46].

Apart from the intensive readings and reflective meetings the mathematics teachers also adopted some strategies to foster student-centres learning. For example, the mathematics teachers developed a responsive classroom environment. These classrooms relaxed the usual tense mathematics classroom environment that has bedevilled the Nigerian mathematics classrooms. There was also the creation of an effective teacher-student relationship which led to increase students' engagement and participation in classroom activities [10] [17] [39]. These mathematics teachers adopted problem solving activities to encourage students' centeredness. This was however used in combination with other 
strategies, like groupings of students, creating effective students-student relationship and teacher-students relationship [10] [14] [30]. The results of which provided solution to dispel the fear of the mathematics teachers who were of the view that when classrooms are student-centred the probability of students disrupting classroom instruction is low. It was however, observed from the study that problem solving help engaged students into profitable discussions that provided no opportunities for distractions [10] [14] [15] [30].

Perceptions of mathematics Teachers and Students on Student-Centered Pedagogy: The finding of this study revealed that the concept of shift from the teacher-control mathematics classroom instruction to a more relaxed classroom environment made learning more collaborative, more student-centred and more student-controlled in a non-authoritative way [30]. The mathematics teachers reflected that the change in their pedagogies encouraged intensive and extensive conversations, students' engagement, inclusive participation and students' direction [15] [30]. Suggesting the importance of an embodiment of a new relationship that should exist between teachers and students and between students grounded in an ongoing dialogue; negotiations, debate and in a collaborative climate which involved participation, integration and interrelatedness between members of the classroom community [14] [31] [64].

The findings of the study also suggested that the students-centred instructions provide opportunities for students to share their experiences and knowledge holistically and celebrate its authenticity through collaboration of ideas with their peers. It ensures the members of the community (students and teachers) were involved in learning communities in which all participants have opportunities to engage in productive discourse [34]. Similarly, it was observed that the mathematics teachers fostered positive relationships with their students, created classroom environments that are more conducive for learning and helped foster social, developmental, emotional and academic needs of their students [17] [19] [62]. The tradition of students' passive involvement in mathematics classroom instruction was gradually replaced with a more collaborative, supportive, participative and inclusive student-centred classroom environment [65].

The findings of the study reveal several other benefits of students' centred learning over the traditional classroom instructions. Such benefits include change in the mathematics teachers domineering attitude [30] [32]. There was a replacement of a tense classroom environment to a more relax classrooms, where ideas are shared, relationships are built through democratic principles as against the traditional authoritarian principles observed in Nigerian mathematics classrooms. The mathematics teachers created opportunities for collaboration between students which helped students' involvement in classroom activities and provided opportunities for more student-directed learning. Hence, the students were not mere passive recipients of knowledge, but rather, were engaged in creating and constructing their knowledge through collaboration of ideas with their peers [10] [18] [62]. 


\section{Conclusions and Recommendation}

In conclusion, this paper sought to look at the four mathematics teachers' effort to shift from the traditional teacher-centered instructions to democratic student-centred classrooms. Three research questions provided direction for the study. The qualitative case study research methodology in a community of practice was adopted in the study. The mathematics teachers taught mathematics in two secondary schools for two years. During this period, 6 Senior Secondary two students willingly volunteered to participate in three focus group discussions on the effectiveness of the mathematics teachers moved from the traditional teacher-centered pedagogy to the student-centred approach. Classroom observations focus groups interviews and reflective interview were used as means of data collection while a narrative approach was adopted to analyze the data collected.

The findings of the study suggest that, the mathematics teachers had initial challenges shifting their traditional believes of the Nigerian mathematics classrooms instruction. The study suggests that certain characteristics of the traditional teacher-centered classrooms were observed. The findings also suggested that the mathematics teachers resolve to shift their philosophy, therefore, developed strategies to foster effective implementation of the epistemology. Some benefits of this strategy were also outlined by the mathematics teachers and the focus group students. They include the relax classroom climate, positive teacher-students' relationship, student self-constructions and development of knowledge. The researcher therefore makes the following recommendations.

- The introduction of student-centered epistemology into the Nigerian mathematics classroom as against the traditional teacher-controlled mathematics classroom is highly recommended.

- It is recommended that student-centred learning approach that encouraged students' collaboration be encouraged in the Nigerian mathematics classrooms.

- The usual teacher-domineering attitude to classroom instruction should be replaced with a more students-centred learning where our students will take responsibility to their learning as promoted by the constructivist epistemologist.

- Constant teachers' development program on teaching strategies, like the innovation employed in this research is highly recommended. This will help our teachers learn new teaching pedagogies and develop new teaching strategies.

- This study suggests that if mathematics teachers adopt the student-centred strategy during their classroom instruction, there will be effective teacher-student and student-student relationship, as against the teacher-focused practice that had dominated the Nigerian mathematics classrooms.

- Finally, it is recommended that further investigation be made using a larger scale with the view of comparing the qualitative and quantitative epistemology to validate the findings of this study. 


\section{Conflicts of Interest}

The author declares no conflicts of interest regarding the publication of this paper.

\section{References}

[1] Pearson, C.L. and Moomaw, W. (2005) The Relationship between Teacher Autonomy and Stress, Work Satisfaction, Empowerment, and Professionalism. Educational Research Quarterly, 29, 38-54.

[2] Davidson, E. (2007) The Pivotal Role of Teacher Motivation in Tanzanian education. The Educational Forum, 71, 157-166. https://doi.org/10.1080/00131720708984928

[3] Ofoegbu, F. (2004) Teacher Motivation: A Factor for Classroom Effectiveness and School Improvement in Nigeria. College Student Journal, 38, 81-88.

[4] Ezekute, O.G. (2000) The Use of Calculators and Computers in Nigerian Schools in the 3rd Millennium: The Journal of the Mathematical Association of Nigeria, 24, 40-50.

[5] Eso, O.T. (1998) Assessment Procedure and Student Locus of Control as Determinants of Achievement in Integrated Science. Unpublished Doctoral Dissertation, University of Ibadan, Ibadan.

[6] Abimbade, A. (1999) Principle and Practice of Educational Technology. International Publishers Ltd., Ibadan.

[7] Feldman, K.A. (1976) The Superior College Teacher from the Students' View. Research in Higher Education, 5, 243-288. https://doi.org/10.1007/BF00991967

[8] Bajah, S.I. (1999) The Challenges of Science Technology and Teacher Education in Nigeria; Beyond the Year 2000. African Journal of Education, 1, 43-49.

[9] Federal Republic of Nigeria (2008) National Policy on Education. 5th Edition, Nigerian Educational Research and Development Council Press, Lagos.

[10] Bature, I.J. and Atweh, B. (2019) Collaboration: A Collective Bargain for Achieving Quality Mathematics Classroom Practice. International Journal of Educational Methodology, 5, 347-361. https://doi.org/10.12973/ijem.5.3.347

[11] Durosaro, I. (1995) Relative Contribution of the Home and the School in Promoting Mental Health of Adolescents. Institute Journal of Studies in Education, University of Ilorin, 1, 118-123.

[12] Sule, O.A. (1995) Improving the Mathematics Teacher's Academics and Professional Inputs in Colleges of Education. Institute Journal of Studies in Education. University of Ilorin, 1.

[13] Abanihe, I., Ifeoma, M., John, L. and Tandi, I. (2010) Evaluation of the Methodology Aspect of the Science Teacher Education Curriculum in Nigeria. Pakistan Journal of Social Sciences, 7, 170-176. https://doi.org/10.3923/pjssci.2010.170.176

[14] Bature, I.J. and Atweh, B. (2016) Achieving Quality Mathematics Classroom Instruction through Productive Pedagogies. International Journal of Educational Methodology, 2, 1-18. https://doi.org/10.12973/ijem.2.1.1

[15] Bature, I.J. and Jibrin, A.G. (2015) The Perception of Preservice Mathematics Teachers on the Role of Scaffolding in Achieving Quality Mathematics Classroom Instruction. International Journal of Education in Mathematics, Science and Technology, 3, 275-287. https://doi.org/10.18404/ijemst.76395

[16] Adewuyi, J.O. and Ogunwuyi, A.O. (2002) Basic Text on Teacher Education. Odu- 
matt Press and Publishers, Oyo.

[17] Bature, I.J. and Bundot, G.B. (2009) Setting the Classroom Climate for Effective Teaching and Learning Process: Implications for Classroom Environment and Learning. International Journal for Contemporary Issues in Education (Special Edition), 198-201.

[18] Bature, I.J. and Bature, F.S. (2009) Students Perception of Environmental Factors Affecting Performance in Mathematics. FCT Educational Secretariat Journal of Curriculum Studies and Instruction: Educational; Resource Centre, Abuja, 3, 41-48.

[19] Bature, I.J. and Zuya, E. (2008) The Mathematics Teachers' Classroom Environment: A Case of Concerned to Secondary School Mathematics Teaching and Learning. Journal of Technology Education, 1, 104-116.

[20] Bristow, S.F. and Patrick, S. (2014) An International Study in Competency Education: Postcards from Abroad. International Association for K-12. Online Learning, Competency Works Issue Brief. https://eric.ed.gov/?id=ED561280

[21] UNESCO (2015) Transversal Competencies in Education Policy and Practice. Phase 1 Regional Synthesis Report, Paris, France.

[22] Adiku, M.U. (2008) Curriculum Development in Science, Technology and Mathematics (STM) Education. Proceedings of the 49th Annual Conference of Science Teachers Association of Nigeria, Nigeria.

[23] Oyedeji, S.O. (2016) Comparison of Senior Secondary Mathematics in Nigeria and China. Journal of Educational Policy and Entrepreneurial Research, 3, 80-99.

[24] NERDC (2013) Lesson Planning Based on Modern Teaching Approaches (For Mathematics). Nigerian Educational Research and Development Council, Sheda.

[25] Igbokwe, D.I. (2000) Dominant Factors and Error Types Inhibiting the Understanding of Mathematics. Proceedings of the 41 st Annual Conference of Science Teachers Association of Nigeria, 242-249.

[26] Ogunbiyi, O. (2004) New Challenges in the Methodologies of Teaching: A Case for in-Service Program for Schoolteachers; Teachers Mandate on Education and Social Development in Nigeria. Stirling-Horden Publishers, Ibadan, Western Nigeria, 152-157.

[27] Brophy, J. (1987) Educating Teachers about Managing Classrooms and Students. Paper Presented at the Annual Meeting of the American Educational Research Association, Washington DC.

[28] Adamu, A.U. (1992) Operation, Efficiency and Desirability of Special Science Schools at the Secondary Education Level: The Nigerian Experience. Paris International Institute of Educational Planning, UNESCO, Paris.

[29] Slavin, R.E. (1990) Cooperative Learning: Theory, Research and Practice. Prentice-Hall, Englewood Cliffs, NJ.

[30] Bature, I.J. and Atweh, B. (2020) Mathematics Teacher's Reflection on the Role of Productive Pedagogies in Improving Their Classroom Instruction. International Journal of Educational Methodology, 6, 319-335. https://doi.org/10.12973/ijem.6.2.319

[31] Bature, I.J., Atweh, B. and Treagust, D. (2016) Inclusivity: An Effective Tool for Achieving Quality Mathematics Classroom Instruction in Nigerian Secondary Schools. Universal Journal of Educational Research, 4, 173-180. https://doi.org/10.13189/ujer.2016.040122

[32] Kaka, M.O. (2007) Games Assisted Instructional Materials; A Strategy for Enhancing Students' Achievement in Integrated Sciences. Journal of Research in Curricu- 
lum and Teaching, 2, 120-128.

[33] Garrett, T. (2008) Student-Centered and Teacher-Centered Classroom Management: A Case Study of Three Elementary Teachers. Journal of Classroom Interaction, 43, 34-47.

[34] Manouchehri, A. and St John, D. (2006) From Classroom Discussions to Group Discourse. Mathematics Teacher, 99, 544-552.

[35] Martin, S.D. (2004) Finding Balance: Impact of Classroom Management Conceptions on Developing Teacher Practice. Teaching and Teacher Education, 20, 405-422. https://doi.org/10.1016/j.tate.2004.04.002

[36] Stodolsky, S.S. (1988) The Subject Matters: Classroom Activity in Math and Social Studies. University of Chicago Press, Chicago, IL.

[37] Good, T. and Brophy, J. (1987) Looking in Classrooms. 4th Edition, Harper and Row, New York.

[38] Schoenfeld, A.H. (1988) When Good Teaching Leads to Bad Results: The Disasters of “Well-Taught” Mathematics Courses. Educational Psychologist, 23, 145-166. https://doi.org/10.1207/s15326985ep2302 5

[39] Abimbade, A. and Afolabi, S.S. (2012) A Study of Pedagogical Approaches of Mathematics Teaching in South-Western States of Nigeria. International Journal of Asian Social Science, 2, 1182-1192.

[40] McNeil, L.M. (1986) Contradictions of Control. Routledge, New York.

[41] Afolabi, O.A. (2004) Influence of Five-Factor Personality Attributes Need for Achievement and Emotional Intelligence on Work Team Interaction Processes. Unpublished Doctoral Thesis, University of Ibadan, Ibadan, Nigeria.

[42] Wilson, M. and Lloyd, G.M. (2000) The Challenge to Share Mathematical Authority with Students: High School Teachers Reforming Classroom Roles. Journal of Curriculum and Supervision, 15, 146-169.

[43] Nesher, P. and Kilpatrick, J. (1990) Mathematics and Cognition: A Research Synthesis by the International Group for the Psychology of Mathematics Education. Cambridge University Press, Cambridge, UK, 1-13. https://doi.org/10.1017/CBO9781139013499

[44] Nelson, R.F. (1997) Teaching Student Teachers How to Promote Cultural Awareness in Urban and Suburban Schools. Paper Presented at the Annual Meeting of the American Association of Colleges for Teacher Education, Phoenix, AZ.

[45] Davis, R.B., Maher, C.A. and Noddings, N. (1990) Constructivist Views on the Teaching and Learning of Mathematics. National Council of Teachers of Mathematics, Reston, VA.

[46] Di Biase, R. (2019) Moving beyond the Teacher-Centered/Learner-Centred Dichotomy: Implementing a Structured Model of Active Learning in the Maldives. Compare: A Journal of Comparative and International Education, 49, 565-583.

[47] Simon, M.A. (2006) Key Developmental Understandings in Mathematics: A Direction for Investigating and Establishing Learning Goals. Mathematical Thinking and Learning, 8, 359-371. https://doi.org/10.1207/s15327833mtl0804 1

[48] Bruner, J. (1990) Acts of Meaning. Harvard University Press, London.

[49] Lave, J. and Wenger, E. (1991) Situated Learning: Legitimate Peripheral Participation. Cambridge University Press, Cambridge. https://doi.org/10.1017/CBO9780511815355

[50] Wallace, D.P. (2007) Knowledge Management: Historical and Cross-Disciplinary 
Themes. Libraries Unlimited, Westport, CT.

[51] Clandinin, D.J. and Connelly, F.M. (2000) Narrative Inquiry: Experience and Story in Qualitative Research. Jossey-Bass, San Francisco, CA.

[52] Braun, V. and Clarke, V. (2006) Using Thematic Analysis in Psychology. Qualitative Research in Psychology, 3, 77-101. https://doi.org/10.1191/1478088706qp063oa

[53] Creswell, J.W. (2014) Research Design: Qualitative, Quantitative and Mixed Methods Approaches. 4th Edition, Sage, Thousand Oaks, CA.

[54] Caulfield, J. (2019) How to Do Thematic Analysis. https://www.scribbr.com/methodology/thematic-analysis/

[55] Carter, M.J. and Fuller, C. (2016) Symbols, Meaning, and Action: The Past, Present, and Future of Symbolic Interactionism. Current Sociology, 64, 931-961. https://doi.org/10.1177/0011392116638396

[56] Evers, J.C. (2016) Elaborating on Thick Analysis: About Thoroughness and Creativity in Qualitative Analysis. Qualitative Social Research, 17, Article No. 6.

[57] Nelson, E. (2017) Re-Thinking Power in Student Voice as Games of Truth: Dealing/Playing Your Hand. Pedagogy, Culture and Society, 25, 181-194. https://doi.org/10.1080/14681366.2016.1238839

[58] Nicole, M. (2018) Addressing Power Struggles in Classrooms and Staff Rooms. Leadership Insight. https://education.cu-portland.edu/blog/leaders-link/confront-power-struggles/

[59] Claire, D., Kit, T., Joy, J. and Roger, L. (2018) Changing Practice in Malaysian Primary Schools: Learning from Student Teachers' Reports of Using Action, Reflection and Modelling (ARM). Journal of Education for Teaching, 44, 194-211. https://doi.org/10.1080/02607476.2018.1433468

[60] Martins, S.A. (1995) Reconstructing Mathematics Pedagogies from a Constructivist Perspectives. Journal for Research in Mathematics Education, 26, 114-145. https://doi.org/10.2307/749205

[61] Emaikwu, S.O. (2012) Assessing the Effect of Prompt Feedback as a Motivational Strategy on Students' Achievement in Secondary School Mathematics. Journal of Educational Research, 3, 371-379.

[62] Atweh, B. (2007) The Social Turn in Understanding Learning and Its Implications for Facilitating Learning: Ripples for Change. A Journey of Preservice Teacher Education Reforms in the Philippines Commission for Higher Education. Print House, Quezon City.

[63] Sawyer, R.K. (2006) Educating for Innovation. The International Journal of Thinking Skills and Creativity, 1, 41-48. https://doi.org/10.1016/j.tsc.2005.08.001

[64] Vitto, J.M. (2003) Relationship-Driven Classroom Management: Strategies that Promote Student Motivation. Corwin Press, Thousand Oaks, CA.

[65] Shulman, L. (2009) Assessment of Teaching or Assessment for Teaching? In: Gitomer, D.H., Ed., Measurement Issues and Assessment for Teaching Quality, Sage Publications, Washington DC. 